\title{
Perspectives
}

\section{Identity, Literacy, and English-Language Teaching}

Bonny Norton

In the field of English-language teaching, there has been increasing interest in how literacy development is influenced by institutional and community practice and how power is implicated in language-learners' engagement with text. In this article, I trace the trajectory of my research on identity, literacy, and English-language teaching informed by theories of investment and imagined communities. Data from English-language classrooms in Canada, Pakistan, and Uganda suggest that if learners have a sense of ownership over meaning-making, they will have enhanced identities as learners and participate more actively in literacy practices. The research challenges English teachers to consider which pedagogical practices are both appropriate and desirable in the teaching of literacy and which will help students develop the capacity for imagining a wider range of identities across time and space. Such practices, the research suggests, will necessitate changes in both teachers' and students' identity.

Dans le domaine de l'enseignement de l'anglais, l'on s'intéresse de plus en plus à l'influence de la pratique institutionnelle et communautaire sur le développement de la littératie, et au rôle du pouvoir dans la mesure dans laquelle les apprenants de langue s'investissent dans le texte. Dans cet article, je dresse la trajectoire de ma recherche qui porte sur l'identité, la littératie et l'enseignement de l'anglais, et qui est informée par les théories de l'investissement et les communautés imaginaires. Des données de classes d'anglais au Canada, au Pakistan et au Ouganda permettent de conclure que si les apprenants ont un sentiment d'appartenance par rapport au sens qu'ils donnent, leur identité comme apprenant sera rehaussée et ils participeront plus activement dans les pratiques littéraires. La recherche met les enseignants d'anglais au défi de considérer quelles pratiques pédagogiques sont à la fois appropriées et désirables dans l'enseignement de la littératie et quelles aideront les étudiants à développer la capacité d'imaginer une gamme plus étendue d'identités au fil du temps et à travers l'espace. La recherche porte à croire que de telles pratiques exigeront des changements tant sur le plan de l'identité des enseignants que celle des étudiants. 


\section{Introduction}

Interest in identity in the field of English-language teaching represents a shift in the field from a focus on psycholinguistic models of second-language acquisition (SLA) toward inclusion of greater interest in sociological and anthropological dimensions of language learning (Norton \& Toohey, 2001; Zuengler \& Miller, 2006). Those of us interested in identity and language learning are concerned not only about linguistic input and output in SLA, but also in the relationship between the language-learner and the larger social world (Block, 2007; Heller, 2007; Kanno, 2008; May, 2008; Norton, 2000; Potowski, 2007; Rampton, 2006; Stein, 2008; Toohey, 2000). Parallel to changes in conceptions of language are changes in prevailing conceptions of literacy in the field of education (Barton, 2007; Blommaert, 2008; Hornberger, 2003; Kress, 2003; Martin-Jones \& Jones, 2000; New London Group, 1996; Prinsloo \& Baynham, 2008). As Luke (1997) notes, whereas earlier psychological perspectives conceived of literacy as the acquisition of particular behaviors, cognitive strategies, and linguistic processing skills, more recent insights from ethnography, cultural studies, and feminist theory have led to increasing recognition that literacy is not only a skill to be learned, but also a practice that is socially constructed and locally negotiated. In this view, literacy is best understood in the context of larger institutional practices, whether in the home, the school, the community, or the larger society. These institutional practices in turn must be understood with reference to what is called the literacy ecology of communities, in which there is frequently inequitable access to social, economic, and political power (Barton; Hornberger). The complex ways that families, schools, and communities interact and differ in their literacy practices provide significant insights into how people learn, teach, negotiate, and access literacy both inside and outside school settings.

These parallel trajectories in the fields of language and literacy education respectively have much in common and have had a great effect on my own research in diverse classrooms in the international community. This plenary has given me the opportunity to address three contexts in which I have sought to explore the subtle connections between literacy, identity, and English-language teaching. The research projects, which were all collaborative, took place in schools in Canada, Pakistan, and Uganda. In Canada, we studied the appeal of Archie comics for young people (Norton, 2003; Norton \& Vanderheyden, 2004; Moffatt \& Norton, 2005); in Pakistan, we investigated perceptions of literacy among middle-school students in Karachi (Norton \& Kamal, 2003); and in Uganda, we investigated how multimodal texts provided enhanced opportunities for learning among secondary school students (Kendrick, Jones, Mutonyi, \& Norton, 2006). In this address, I present the central findings from each of these three research projects, focusing on the 
relationship between literacy, identity, and English-language teaching, with particular reference to my recent work on investment and imagined communities, as discussed below.

\section{Theoretical Framework: Investment and Imagined Identities}

In ongoing research (Norton Peirce, 1995; Norton, 2000, 2010; Norton \& Gao, 2008), I have sought to integrate poststructuralist conceptions of identity and human agency by developing a construct I have called investment. Departing from current conceptions of motivation in the field of language-learning, the concept of investment signals the socially and historically constructed relationship of learners to the target language and their sometimes ambivalent desire to speak, read, or write it. Investment is best understood with reference to the economic metaphors that Bourdieu $(1997,1991)$ uses in his work, in particular the notion of cultural capital. Cultural capital is situated in that it has differential exchange value in varied social fields. In my work, I have argued that if learners invest in a second language, they do so with the understanding that they will acquire a wider range of symbolic and material resources, which will in turn increase the value of their cultural capital. As the value of their cultural capital increases, so learners' sense of themselves, their identities, and their opportunities for the future are reevaluated. Hence there is an integral relationship between investment and identity. This notion of investment has been taken up by other scholars in the field and is proving productive for understanding the complex conditions in which languagelearning takes place (Arkoudis \& Davison, 2008; Cummins, 2006; Haneda, 2005; McKay \& Wong, 1996; Pittaway, 2004; Potowski, 2007; Skilton-Sylvester, 2002).

Through reference to imagined communities and imagined identities (Norton, 2001; Kanno \& Norton, 2003; Pavlenko \& Norton, 2007), we refer to groups of people-not immediately tangible and accessible-with whom we connect through the power of the imagination. In our daily life, we interact with many communities whose existence can be felt concretely and directly such as our neighborhood communities, our workplaces, our educational institutions, and our religious groups. However, these are not the only communities with which we are affiliated. Imagined ties can extend both spatially and temporally (Anderson, 1991). Thus in imagining themselves bonded with their fellow human beings across space and time, learners can feel a sense of community with people they have not yet met, including future relationships that exist only in a learner's imagination. We suggest that these imagined communities are no less real than those where learners have daily engagement and might even have a stronger effect on their current actions and investments. Further, we have made the case that an investment in an imagined community assumes an investment in an imagined identity, one that may continually change across time and space. 


\section{Research Across Time and Space}

Archie comics and the power of popular culture in Canada. Archie comics, which address the lives of a group of adolescents in the United States, are popular in Canada and indeed in many parts of the world and are widely read by pre-adolescent children, $60 \%$ of whom are girls. In embarking on this research (Norton, 2003; Norton \& Vanderheyden, 2004; Moffatt \& Norton, 2005; Moffatt \& Norton, 2008), our aim was not to promote or denounce Archie comics, but to understand better the ubiquitous Archie reader and to determine if insights from Archie readers might have significance for language and literacy education. The research was conducted in a Vancouver elementary school from 1998 to 1999 and involved 55 elementary students aged 10-12, 25 of whom were English-language learners.

In our research we found that Archie comic readers were subject to an interesting set of power relationships in their home and school contexts. Students noted that their parents and teachers were frequently dismissive of their love for comic books, describing them as "garbage" and "a waste of time." Archie readers had incorporated such views in their own understandings of literacy, drawing a distinction between what research participants called "real reading" and "fun reading." "Real reading," in their view, was reading that the teacher prescribed; it was "educational"; it was "challenging"; but it was seldom "fun." The reading of Archie comics was "fun" because readers could construct meaning, make hypotheses, and predict future developments without trying to second-guess the teacher. Our findings suggest that the inequitable relationships of power between teachers and parents on the one hand and children on the other may limit a child's engagement with text, sometimes rendering it a meaningless ritual.

Two related observations from the research are relevant to an exploration of the relationship between identity and literacy. First, the Archie study suggests that the pleasure children derive from comics in general, and from Archie comics in particular, is associated with a sense of ownership over meaning-making, whether the readers are native speakers or English-language learners. It is this sense of ownership that gives children the confidence to engage with comic books both energetically and critically. For the Archie comic readers in our study, their goal in debating the merits of characters, events, and stories was not to anticipate other interpretations and critiques, but to draw on their own knowledge and experience to reflect, engage, and defend. However, although the study provides much evidence to suggest that the Archie reading community was vibrant and social, and helped to strengthen relationships between native speakers and English-language learners, the children's reading preferences received little recognition or validation from teachers or parents. The study suggests that literacy educators need to understand better rather than dismiss those practices that students find engaging and meaningful, whether in or outside classrooms. 
Indeed, the Archie comic study led us to rethink the notions of reading, literacy, and learning. The written word, although still important, is only one of the many semiotic modes that children encounter in the various domains of their lives. From popular culture, drama, and oral storytelling to television and the Internet, children in many parts of the world are engaging in diverse ways with multiple texts. The challenge for literacy educators is to reconceptualize classrooms as semiotic spaces where children have the opportunity to construct meaning with a wide variety of multimodal texts, including visual, written, spoken, auditory, and performative texts. Scaffolding such a curriculum is a theory of meaning-making in which children are not only the users, but also the makers of systems of communication.

\section{Literacy and Imagined Communities in Pakistan}

In this 2001-2002 research study (Norton \& Kamal, 2003), students in Karachi, Pakistan, took part in a global social action project called the Youth Millennium Project, in which 80 middle school students calling themselves "The Reformers" collected stationery, books, and supplies for a local orphanage serving Afghan refugee children. Part of the project was also to teach the Afghan children what we referred to as "some simple English phrases." We were intrigued by the students' interest in literacy and their promotion of the English language. We were also curious about the vision of the future held by these students at a time of great social and political instability. We collected data on these issues through questionnaires, interviews, observations, and e-mail exchanges. The following findings inform our understanding of the relationship between identity, literacy, and English-language teaching.

First, we were interested to find that the students' conceptions of literacy were consistent with many current theories of literacy in the scholarly literature. The students held the view that literacy is not only about reading and writing, but also about education more broadly. "Literacy plays a vital role in the progress of a country," said one, and another noted passionately that "without education our beloved country Pakistan cannot develop." Other students, however, extended this view to include the notion that a literate person has greater ability to reason than one who is illiterate. One student, for example, noted that a literate person "can make better decisions" than an illiterate person, and another said, "If we are not literate we cannot do any work with thinking." These same students noted, in addition, that material resources are needed to promote both literacy and development. They pointed out, for example, that what they called the Afghan "childlabours" in their community could not access literacy classes because they were supporting their destitute families. The students were well aware of the resources of wealthier countries, noting somewhat optimistically, "We know that in developed countries everyone is educated and goes to school; that is why they 
are rich and have no problems." For students in Pakistan, literacy must be understood with reference to social, economic, and political power.

Like their notions of literacy, the students' responses to the importance of English were complex and best understood in the context of Pakistan's ambivalent status in the international community. In seeking to teach the Afghan children "some simple English phrases," students were invested in the belief that English is an international language and the language of science, technology, and the media. As one said, "The English language is an international language spoken all over the world and it is the language of science. Therefore, to promote their education and awareness with modern technologies, it is important to teach them English."

Students noted that English serves as a common language not only across nations, but also in nations, and expressed the hope that knowledge of English would redress imbalances between developed and developing nations. With only a few exceptions, the students demonstrated little ambivalence toward the English language and perceived it as an important tool for social, economic, and political advancement, both in Pakistan and the international community. When students were pressed to consider whether the spread of English had any negative consequences, only two noted that a country's native languages could be compromised, and only one noted that the spread of English would be accompanied by the spread of western culture, what he called "a bad sign." In sum, students expressed the hope that in a future Pakistan all inhabitants were literate, knowledgeable about English, and technologically advanced. They wanted a peaceful society, true to the principles of Islam and respected in the international community.

Insights from these students are best understood in the context of their complex identities in a time of social and political instability, both nationally and internationally. The research suggests that the struggle for literacy, access to English, and technological progress are interdependent and reflect the desire of a country in a postcolonial world to engage with the international community from a position of strength rather than weakness. The findings suggest further that English and the vernacular can coexist in mutually productive ways and that the appropriation of English does not necessarily compromise identities structured on the grounds of linguistic or religious affiliation.

\section{Learning English Through Multimodal Texts in Uganda}

In one of our diverse research projects in Uganda, we have found that multimodal texts that include drama, photography, and drawing - although by no means new pedagogies-could be incorporated more systematically into English-language teaching in the country (Kendrick et al., 2006). In one study, by way of example, we examined how drama was used in HIV/AIDS 
clubs to communicate information and advice to the student body (Norton \& Mutonyi, 2007). As one student leader said,

You see, students will usually not turn up in big numbers when you are giving a talk on HIV / AIDS. So we thought that maybe if we organize the drama as a sort of entertainment for the school, we could have many students attending and we can use the opportunity to talk about HIV / AIDS. The drama is always about HIV/AIDS but it is also fun so students come to watch and listen.

We found that drama gave students, and girls in particular, the opportunity to adopt new identities and speak from diverse subject positions. In this context, in which discussions of sexuality and sexual relations are frequently taboo, drama gave students the opportunity to perform the unsayable (Stein, 2008) and raise gendered issues that are traditionally marked by silence. In this regard, the motto of one of the HIV/AIDS clubs is compelling: "Talk what others think you can't talk."

In another project, we worked with 19 secondary school girls in Senior 3 (ages 16-19) to explore the use of photography as a multimodal pedagogy (Kendrick \& Jones, 2008). The purpose of this activity was to provide the girls with a visual, artistic way to explore and view specific aspects of their lives through the lens of the camera and to develop communicative English capacity by using photography as an entry point for discussion, reading, writing, and critique. Through journal-writing and conversations, the girls discussed what they had learned through their participation in the photography project such as how their experience with the camera made them feel more confident about learning about other types of technology. Of particular note, however, was that almost all the girls also mentioned the improvement in their English-language competence. When asked directly how (if at all) they believed that this project facilitated learning English, the girls mentioned reading comprehension (as a result of studying the manuals); writing (writing in their research journals); and listening and speaking (from group discussions, meetings, and presentations). In addition, they said that their participation in this project also served to improve their school English. In a conversation with Shelley Jones, a member of our research team, one of the girls (Rose) expressed the following point in relation to learning English.

Shelley: How is learning English through doing a project like this different from learning English in the classroom?

Rose: In class teachers write on the blackboard and we just listen.

Shelley: In the ... project how do you use English?

Rose:Communication.

Shelley: Do you learn more by studying English or by communicating in English?

Rose: Communicating. 


\section{Shelley: Why?}

Rose: Because when you communicate, you think your own English.

Kendrick and Jones (2008) have argued further that the visual images provided a key to understanding how and why the girls engaged in particular literacy practices, and what this engagement meant for their imagined identities and desired futures. As they noted, "For these girls, the freedoms associated with English, education, status, safety, space, and time were not only fundamental to their imagined communities, but represent the pre-requisites for full participation in the literacy world" (p. 396).

\section{Discussion}

In these three research projects, English-language learners had complex investments in their respective literacy practices, and each of these investments was associated with a range of identities, including those of the imagination. The readers of Archie comics in Canada were invested in these popular cultural texts because they had a sense of ownership over meaning-making. With respect to reader identities, students were in a position of relative power in which they could actively construct the meaning of the popular cultural text. In teacher-controlled texts, by contrast, the students were in a position of relative powerlessness and sought primarily to second-guess the teacher.

In Pakistan, language-learners were invested in literacy and the English language because they wanted to appropriate identities as "educated" people, living in a "developed" country, with access to both symbolic and material resources. However, it is of some concern that students might in fact overestimate the benefits that can accrue from the development of literacy and the spread of English (May, 2008; Pennycook, 1998). The assessment, for example, that people who are educated "are rich and have no problems" may lead to a crisis of expectations. Of even greater concern is how pedagogical and social practices may be serving, perhaps inadvertently, to reinforce the view held by the students that people who are literate are more rational and intellectually able than those who are not literate. If students in Pakistan, and perhaps in other parts of the world, equate literacy with rationality and intellectual ability while also embracing English as the international language of science, media, and technology, is there a danger that they may consider people who are literate in English as more rational and intellectually able than those who are not?

In Uganda, the secondary schoolgirls were invested in drama and photography because these diverse media gave the girls the opportunity to explore a range of identities, many hitherto unexplored. In particular, the girls could reflect on the conditions that constrained the range of identities available to them, and those that provided an enhanced range of possibilities for the 
future. With regard to gendered identities, Stein (2008) noted that in a world where adolescent sexuality is culturally marked by silence, and young girls are vulnerable to sexual assault by boys and older men, a range of semiotic modes should be drawn on to express fear, violation, pain, and loss. The implications for English-language pedagogy are profound.

\section{Implications for English-Language Teaching}

This research trajectory raises two central concerns that have particular relevance to English-language teaching. First, consistent with the research of scholars such as Canagarajah (1999), Luke (2004), Ramanathan (2005), and Street (2001), I learned from many of these students that if we wish to understand the meaning of literacy in students' lives, we cannot ignore the imperatives of the material world and how resources are distributed, not only nationally, but internationally. Canagarajah (1999) made a compelling case that in developing countries where there is a daily struggle for food, clothing, shelter, and safety, researchers cannot indulge in theoretical debates and abstract policies, but need to address the material realities of the communities in which we conduct research. Luke (2004) similarly argued that while we as educators might debate the meaning of critical literacy, we may not do justice to the experiences of physical and material deprivation in diverse communities throughout the globe. The students in Pakistan and Uganda were well aware of the relationship between literacy, the distribution of resources, and human possibility. For these students and many others in development contexts, a community that is literate and skilled in English is also a community that has social, economic, and political power.

Second, it was 20 years ago (Norton Peirce, 1989) that I raised the question of how notions of communicative competence are framed in the field of English-language teaching (Leung, 2005; Wallace, 2003; Kramsch \& Whiteside, 2008). I made the case that a concern for the rules of use in the teaching of English internationally is an inadequate pedagogical goal if teachers are concerned about the relationship between language, identity, and human possibility. In raising the question Whose interests do such rules serve? I made the case that theories of communicative competence need to address not only what is appropriate, but what is desirable in the teaching of English internationally (McKinney \& Norton, 2008). The research I have conducted over the last 20 years suggests that these concerns remain current in the field of English-language teaching, and that the debate has now been extended to include the effect of global technologies on teaching languages (Kress, 2003; Lam, 2000; Rassool, 1999; Snyder \& Prinsloo, 2007; Warschauer, 2003). Rassool, for example, argued that communicative competence in a technological global world refers to the interactive process in which meanings are produced dynamically between information technology and experience. The extent to which we are informed will in turn affect the extent to 
which we respond to and act on our understanding. In this regard, she argued, the principles of democracy are at stake.

\section{Conclusion}

In this article, I draw on my critical literacy research in Canada, Pakistan, and Uganda to make the case that literacy is not only about reading and writing, but also about relationships between text and reader, student and teacher, classroom and community, in local, regional, and transnational sites. As such, when learners engage in literacy practices, they are also engaged in acts of identity. As English teachers, we need to take seriously the findings, which suggest that if learners have a sense of ownership of meaning-making, they can engage actively in a wide range of literacy practices; however, if there is little ownership over meaning-making, learning becomes meaningless and ritualized. Further, the studies suggest that meaning-making is facilitated when learners are in a position of relative power in a given literacy event. Students in diverse parts of the world have suggested that parents and teachers are often dismissive of the range of texts, including oral, written, drawn, or performed, in which they are invested. My research suggests that many of these texts provide students with the opportunity to explore a range of identities, including those of the imagination, which enable them to "think their own English." As language educators, the research challenges us to consider what pedagogical practices will help students develop the capacity for imagining a range of identities for the future. What shifts of teacher identity will such practices necessitate? These are intriguing and important questions for English teachers internationally.

\section{Note}

This article is a slightly revised version of Norton (2010). Identity, literacy, and English language teaching presented at the IATEFL conference in Cardiff.

\section{The Author}

Bonny Norton is a professor and Distinguished University Scholar in the Department of Language and Literacy Education, University of British Columbia. Her research addresses identity, language-learning, critical literacy, and international development. Her Web site is http://lerc.educ.ubc.ca/fac/norton/

\section{References}

Anderson, B. (1991). Imagined communities: Reflections on the origin and spread of nationalism (rev. ed.). New York: Verso.

Arkoudis, S., \& Davison, C. (Eds.). (2008). Chinese students: Perspectives on their social, cognitive, and linguistic investment in English medium interaction. Journal of Asian Pacific Communication, 18(1), 3-8.

Barton, D. (2007). Literacy: An introduction to the ecology of written language (2nd ed.). Malden, MA: Blackwell.

Block, D. (2007). Second language identities. London: Continuum. 
Blommaert, J. (2008). Grassroots literacy: Writing, identity, and voice in Central Africa. London, New York: Routledge.

Bourdieu, P. (1977). The economics of linguistic exchanges. Social Science Information, 16(6), 645-668.

Bourdieu, P. (1991). Language and symbolic power (J.B. Thompson, Ed.; G. Raymond \& M. Adamson, Trans.). Cambridge, UK: Polity Press.

Canagarajah, A.S. (1999). Resisting linguistic imperialism in English teaching. Oxford, UK: Oxford University Press.

Cummins, J. (2006). Identity texts: The imaginative construction of self through multiliteracies pedagogy. In O. Garcia, T. Skutnabb-Kangas, \& M.M. Torres-Guzman (Eds.), Imagining multilingual schools: Languages in education and glocalization (pp. 51-68). Clevedon, UK: Multilingual Matters.

Haneda, M. (2005). Investing in foreign-language writing: A study of two multicultural learners. Journal of Language, Identity, and Education, 4(4), 269-290.

Heller, M. (2007). Linguistic minorities and modernity: A sociolinguistic ethnography (2nd ed.). London: Continuum.

Hornberger, N.H. (Ed.). (2003). Continua of biliteracy: An ecological framework for educational policy, research, and practice in multilingual settings. Clevedon, UK: Multilingual Matters.

Kanno, Y. (2008). Language and education in Japan: Unequal access to bilingualism. Basingstoke, UK: Palgrave Macmillan.

Kanno, Y., \& Norton, B. (Eds.). (2003). Imagined communities and educational possibilities: Introduction. Journal of Language, Identity, and Education, 2(4), 241-49.

Kendrick, M., \& Jones, S. (2008) Girls' visual representations of literacy in a rural Ugandan community. Canadian Journal of Education, 31(2), 371-404.

Kendrick, M., Jones, S., Mutonyi, H., \& Norton, B. (2006). Multimodality and English education in Ugandan schools. English Studies in Africa, 49(1), 95-114.

Kramsch, C, \& Whiteside, A. (2008). Language ecology in multilingual settings: Towards a theory of symbolic competence. Applied Linguistics, 29(4), 645-671.

Kress, G. (2003). Literacy in the new media age. London: Routledge.

Lam, W.S.E. (2000). L2 literacy and the design of the self: A case study of a teenager writing on the Internet. TESOL Quarterly, 34, 457-482.

Leung, C. (2005). Convivial communication: recontextualizing communicative competence. International Journal of Applied Linguistics, 15(2), 119-144.

Luke, A. (1997). Critical approaches to literacy. In V. Edwards \& D. Corson (Eds.), Encyclopedia of language and education, Vol. 2: Literacy (pp. 143-152). Dordrecht, Netherlands: Kluwer Academic.

Luke, A. (2004). Two takes on the critical. In B. Norton \& K. Toohey (Eds.), Critical pedagogies and language learning (pp. 21-29). New York: Cambridge University Press.

Martin-Jones, M., \& Jones, K. (Eds.). (2000). Multilingual literacies: Reading and writing different worlds. Amsterdam: John Benjamins.

May, S. (2008). Language and minority rights: Ethnicity, nationalism and the politics of language. London: Routledge.

McKay, S.L., \& Wong, S. C. (1996). Multiple discourses, multiple identities: Investment and agency in second-language learning among Chinese adolescent immigrant students. Harvard Educational Review, 66, 577-608.

McKinney, C., \& Norton, B. (2008). Identity in language and literacy education. In B. Spolsky \& F.M. Hult (Eds.), The handbook of educational linguistics (pp. 192-205). Malden, MA: Blackwell.

Moffat, L., \& Norton, B. (2005). Popular culture and the reading teacher: A case for feminist pedagogy. Critical Inquiry in Language Studies, 2(1), 1-12.

Moffatt, L., \& Norton, B. (2008). Reading gender relations and sexuality: Preteens speak out. Canadian Journal of Education, 31(1) 102-123. 
New London Group. (1996). A pedagogy of multiliteracies: Designing social futures. Harvard Educational Review, 66, 60-93.

Norton, B. (2000). Identity and language learning: Gender, ethnicity and educational change. Harlow, UK: Longman/Pearson.

Norton, B. (2001). Non-participation, imagined communities, and the language classroom. In M. Breen (Ed.), Learner contributions to language learning: New directions in research (pp. 159-171). London: Pearson Education.

Norton, B. (2003). The motivating power of comic books: Insights from Archie comic readers. Reading Teacher, 57(2), 140-147.

Norton, B. (2010). Identity, literacy, and English language teaching. Paper presented at the IATEFL conference, Cardiff.

Norton, B. (2010). Language and identity. In N.H. Hornberger \& S.L. McKay (Eds.), Sociolinguistics and language education (pp. 349-369). Clevedon, UK: Multilingual Matters.

Norton, B., \& Gao, Y. (2008). Identity, investment, and Chinese learners of English. Journal of Asian Pacific Communication, 18(1), 109-120

Norton, B., \& Kamal, F. (2003). The imagined communities of English language learners in a Pakistani school. Journal of Language, Identity, and Education, 2(4), 301-317.

Norton, B., \& Toohey, K. (2001). Changing perspectives on good language learners. TESOL Quarterly, 35, 307-322.

Norton, B., \& Vanderheyden, K. (2004). Comic book culture and second language learners. In B. Norton \& K. Toohey (Eds.), Critical pedagogies and language learning (pp. 201-221). New York: Cambridge University Press.

Norton, B., \& Mutonyi, H. (2007). "Talk what others think you can't talk": HIV / AIDS clubs as peer education in Ugandan schools. Compare: A Journal of Comparative Education, 37(4), 479-492.

Norton Peirce, B. (1989). Toward a pedagogy of possibility in the teaching of English internationally: People's English in South Africa. TESOL Quarterly, 23, 401-420.

Norton Peirce, B. (1995). Social identity, investment, and language learning. TESOL Quarterly, 29, 9-31.

Pavlenko, A., \& Norton, B. (2007). Imagined communities, identity, and English language learning. In J. Cummins \& C. Davison (Eds.), International handbook of English language teaching (pp. 669-680). New York: Springer.

Pennycook, A. (1998). English and the discourses of colonialism. New York: Routledge.

Pittaway, D.S. (2004). Investment and second language acquisition. Critical Inquiry in Language Studies, 1(4), 203-218.

Potowski, K. (2007). Language and identity in a dual immersion school. Clevedon, UK: Multilingual Matters.

Prinsloo, M., \& Baynham, M. (Eds.) (2008). Literacies, global and local. Philadelphia, PA: John Benjamins

Ramanathan, V. (2005). The English-vernacular divide: Postcolonial language politics and practice. Clevedon, UK: Multilingual Matters.

Rampton, B. (2006). Language in late modernity: Interaction in an urban school. Cambridge, UK: Cambridge University Press

Rassool, N. (1999). Literacy for sustainable development in the age of information. Clevedon, UK: Multilingual Matters.

Skilton-Sylvester, E. (2002). Should I stay or should I go? Investigating Cambodian women's participation and investment in adult ESL programs. Adult Education Quarterly, 53(1), 9-26.

Snyder, I., \& Prinsloo, M. (2007). Young people's engagement with digital literacies in marginal contexts in a globalised world. Language and Education: An International Journal, 21(3), 171-179.

Stein, P. (2008). Multimodal pedagogies in diverse classrooms: Representation, rights and resources. London: Routledge. 
Street, B.V. (2001) (Ed.). Literacy and development: Ethnographic perspectives. New York: Routledge.

Toohey, K. (2000). Learning English at school: Identity, social relations and classroom practice. Clevedon, UK: Multilingual Matters.

Wallace, C. (2003). Critical reading in language education. Basingstoke, UK: Palgrave Macmillan.

Warschauer, M. (2003). Technology and social Inclusion: Rethinking the digital divide. Boston, MA: MIT Press

Zuengler, J., \& Miller, E.R. (2006). Cognitive and sociocultural perspectives: Two parallel SLA worlds? TESOL Quarterly, 40, 35-58. 